\title{
bastlot
}

\section{O problema da identidade entre açóes eleitoraisł da litispendência e da coisa julgada à ação temática eleitoral}

Roberta Maia Gresta ${ }^{1}$ (UFMG, Brasil)

robsgresta@gmail.com

Tribunal Regional Eleitoral de Minas Gerais,

Assessoria Jurídica dos Juízes Membros da Corte Regional Eleitoral.

Avenida Prudente de Morais, 100, Cidade Jardim

1. Doutoranda em Direito Político (UFMG). Mestre em Direito Processual (PUC Minas). Professora de Graduação em Direito (Faculdade Arnaldo) e de Pós-graduação lato sensu (diversas instituições). Assessorachefe de Gabinete de Juiz Membro (TRE/MG). Instrutora colaboradora (EJE-TRE/MG). 


\title{
Resumo
}

O presente artigo aborda o problema da identidade entre as ações eleitorais que versam sobre a legitimidade das candidaturas, das eleiçóes e de seus resultados. A partir da análise dos elementos dessas açóes - partes, pedido e causa de pedir -, promove-se a crítica ao tratamento dado à questão pela jurisprudência do TSE e, mais recentemente, pela alteração promovida pela Lei 13.165/2015, que inseriu o art. 96-B na Lei 9.504/97. Na condução da argumentação, será tomada, como marco teórico, a compreensão de processo coletivo democrático apresentada por Vicente de Paula Maciel Júnior e que resultou, na pesquisa deste, à enunciação da ação temática. Ao final, apresenta-se a ação temática eleitoral, proposta de estruturação dos procedimentos eleitorais em compatibilidade com o caráter coletivo destes.

Palavras-chave: Direito processual eleitoral. Processo coletivo democrático. Minirreforma eleitoral de 2015. Devido processo legal.

\section{The problem of identity between electoral legal actions: from lis pendens and res judicata to lawsuits on electoral matters}

\begin{abstract}
This article discusses the problem of identity between electoral actions relating to the legitimacy of candidacies, elections and their results. From the analysis of the elements of these actions - parties, plea and cause of action - , it criticizes the way this issue is treated by the jurisprudence of the TSE and, more recently, by an amendment promoted by Law $13165 / 2015$, which introduced rule $96-\mathrm{B}$ in Law 9504/97. To conduct the argument, it is taken, as theoretical reference, the comprehension of democratic collective process offered by Vicente de Paula Maciel Júnior, which resulted, in his research, in the enunciation of thematic action. In the end, the electoral thematic action is presented as a proposal for structuring electoral procedures in compliance with their collective character.
\end{abstract}

Keywords $¥$ Electoral procedural law. Democractic collective process. 2015’s electoral minireform. Due process. 


\section{Introdução}

As reiteradas alterações da legislação eleitoral desde o advento da Constituição de $1988^{473}$ sinalizam que a conformação das regras aplicáveis ao processo político para formação de governos e parlamentos é um constante objeto de debate. Diante de deficiências - aferidas ou meramente supostas - do sistema vigente, o Congresso Nacional tem conduzido debates e apresentado respostas que, bem ou mal, vêm tornando o Direito Eleitoral mais densamente normatizado e complexo. No entanto, vem-se relegando, nessa dinâmica, um importantíssimo aspecto: a regulamentação dos procedimentos judiciais nos quais se questiona o registro dos candidatos, a outorga de diplomas e a titularidade dos mandatos eletivos.

A legislação eleitoral regulamenta, hoje, dois procedimentos judiciais para encaminhar pretensões de impedir a aquisição ou cassar registros, diplomas e mandatos: o da ação de impugnação ao registro de candidatura (AIRC, arts. $3^{\circ}$ A 16 da LC 64/90) e o da ação de investigação judicial eleitoral (AIJE, arts. 22 a 24 da LC 64/90). Embora sejam apenas dois os procedimentos descritos, existem mais ações previstas. As representações específicas (arts. 30-A, 41-A e 73 da Lei 9.504/97) submetem-se ao procedimento da AIJE, por expressa previsão legal, enquanto a ação de impugnação ao mandato eletivo (AIME, cujas causas de pedir são delimitadas no art. $14, \S 10 \mathrm{da} C R / 88$ ) é submetida, por força de precedente jurisprudencial ${ }^{474}$, ao procedimento da AIRC. Ao recurso contra a expedição de diploma (RCED, cujas causas de pedir são previstas no art. 262 do Código Eleitoral), tem-se aplicado o procedimento dos recursos eleitorais, em especial o art. 267 do Código Eleitoral.

É desafiador caracterizar essa multiplicidade de ações a partir dos elementos indicados pela teoria geral do processo - partes, causa de pedir e pedido -, estabelecer em que situação duas ou mais ações podem ser reputadas idênticas e, por fim, fixar solução para esse problema. Primeiro, a legitimação ativa para as ações eleitorais é concorrente e disjuntiva, o que significa que, em tese, Ministério Público Eleitoral, partidos políticos, coligações e candidatos podem propor açóes que tenham em comum a causa de pedir e o pedido. Deve-se, nessa situação, reconhecer a autonomia entre tais ações? Segundo, a cassação do registro, do diploma o do mandato têm efeito prático similar, sustentando-se como institutos distintos apenas em razão do momento em que proferida a decisão. É possível sustentar que duas ações eleitorais não sejam idênticas apenas porque em uma se pede a cassação do diploma e, em outra, a do mandato? Terceiro, como as variadas causas de pedir jurídicas podem recair sobre uma mesma causa de pedir fática, tem-se frequentemente a possibilidade de sobreposição de ações destinadas a discutir os mesmos fatos. Em que medida a diversidade da causa de pedir jurídica é determinante para se distinguir tais ações?

O presente artigo aborda o tratamento dado a tais questôes pela jurisprudência do TSE e, mais recentemente, pela alteração promovida pela Lei 13.165/2015, que inseriu o art. 96-B

473. Dentre as principais alterações, devem ser citadas: 1) As Emendas Constitucionais 4/93, 16/97, 52/2006 e 582009 e a Emenda Constitucional de Revisão 4/94; O advento da Lei das Eleiçóes, Lei 9.504/97; 2) A revogação da LC 5/70 pela LC 64/90, atual Lei das Inelegibilidades; 3) A revogação da Lei 5.682/71 pela Lei 9.096/95, atual Lei dos Partidos Políticos; 4) As sucessivas “minirreformas" promovidas pelas Leis 11.300/2006, 12.034/2009, 12.891/2013 e 13.165/2015; 5) O advento da Lei da Ficha Limpa, LC 135/2010.

474. BRASIL. Tribunal Superior Eleitoral. Recurso Especial Eleitoral n. 11835, Relator Min. Torquato Lorena Jardim. Acórdão de 09 jun. 1994. Publicado no Diário de Justiça em 29 jul 1994, p. 18429. In: Revista de Jurisprudência do TSE, v. 6, tomo 3, p. 132. 
na Lei 9.504/97. Argumenta-se que tal tratamento é inadequado, por não ser capaz de promover a compreensão e a estruturação das ações que discutem a legitimidade de candidaturas, diplomas e mandatos a partir de premissas do processo coletivo. Na condução da argumentação, será tomada, como marco teórico, a compreensão de processo coletivo democrático apresentada por Vicente de Paula Maciel Júnior e que resultou, na pesquisa deste, à enunciação da ação temática.

Ao final, propõe-se que a ação temática, concebida por Maciel Júnior como procedimento apto encaminhar a ação civil pública e outras ações coletivas, seja também adotada no âmbito eleitoral, como técnica adequada à solução do problema da identidade entre açóes eleitorais. Apresenta-se, então, a ação temática eleitoral, estruturada de modo não polarizado, mas radial, em torno de dois grandes temas: a legitimidade das candidaturas e a legitimidade das eleições e de seu resultado.

\section{Os elementos das ações eleitorais que versam sobre candidaturas, diplomas e mandatos $\$$ partes, pedido e causa de pedir}

Elementos da ação são "os componentes mínimos e suficientes da ação que as identificam como tais e, consequentemente, as distinguem de quaisquer outras ações" ${ }^{\prime \prime 75}$. São também chamados "elementos identificadores da demanda" ${ }^{476}$, uma vez que constituem eles o núcleo essencial para que seja dado o impulso inicial ao exercício da função judicial.

Segundo regra geral do processo civil, a identidade de açóes deve ser aferida a partir da tríplice coincidência dos elementos da ação: "uma ação é idêntica a outra quando possui as mesmas partes, a mesma causa de pedir e o mesmo pedido" (art. 337, $\$ 2^{\circ}, \mathrm{CPCP} / 2015$ ). Litispendência e coisa julgada, como pressupostos processuais negativos, indicam a impossibilidade de que venha a ser repetida ação idêntica a outra anteriormente ajuizada, esteja essa ainda em curso ou já julgada (art. 337, $\$ \$ 1^{\circ}$ a $4^{\circ}, \mathrm{CPC} / 2015$ ). Na ausência de regras expressas na legislação eleitoral, essas disposições orientam o tratamento das ações eleitorais. Por isso, o enfrentamento do problema da identidade entre açóes eleitorais deve principiar pelo esforço de compreender os elementos identificadores demandas eleitorais.

A tarefa não é simples. A previsão legal de ações eleitorais que propiciam a discussão de candidaturas, diplomas e mandatos carece de sistematização. Quatro fontes normativas concorrem para enunciar ilícitos eleitorais e irregularidades que podem redundar em impedimento, cassação ou desconstituição daqueles. Não há uniformidade na técnica de enunciação, que pode se limitar à causa de pedir, ao pedido ou, mesmo, à referência ao procedimento.

Assim, a CR/88 prevê a impugnação do mandato em caso de abuso de poder econômico, corrupção ou fraude (art. 14, §10). O Código Eleitoral diz ser cabível o RCED em caso de inelegibilidade infraconstitucional superveniente ao registro de candidatura, inelegibilidade

475. BUENO, Cassio Scarpinella. Curso sistematizado de direito processual civil: teoria geral do direito processual civil. 5. ed. São Paulo: Saraiva, 2011, p. 415.

476. CÂMARA, Alexandre Freitas. Liçòes de direito processual civil: volume 1. 25. ed. São Paulo: Atlas, 2014, p. 266. 
constitucional ou falta de condição de elegibilidade (art. 262). A LC 64/90 trata da impugnação ao registro de candidatura, que pode redundar, em caso de declaração de inelegibilidade, na negativa ou cancelamento do registro de candidatura ou na nulidade do diploma ( $\operatorname{art} .3^{\circ}$ e 15), bem como do abuso do poder econômico e do poder de autoridade e da utilização indevida de veículos ou meios de comunicação social em benefício de candidato ou de partido político como ensejadoras da cassação do registro ou diploma (art. 22). A Lei 9.504/97 arrola a captação e o gasto ilícito de recursos de campanha, a captação ilícita de sufrágio, as condutas vedadas aos agentes públicos em campanha e o abuso de autoridade como práticas ilícitas que podem conduzir à cassação do registro ou diploma ou a sanção equivalente (arts. 30-A, 41-A, 73 e 74).

Constitui desafio permanente da literatura e da jurisprudência delimitar os elementos dessas ações eleitorais e estabelecer implicações mútuas entre elas. A seguir, a abordagem legal e jurisprudencial desses elementos será exposta de forma sucinta e crítica, limitadamente aos aspectos relevantes para o desenvolvimento do presente artigo.

\subsection{Partes}

Nessa seção, o principal enfoque recai sobre a legitimidade ativa das ações eleitorais, que produzirá questionamentos relevantes quanto à identidade entre aquelas. Sobre a legitimidade passiva, basta aqui assinalar que, embora outras figuras possam acidentalmente integrar o polo passivo dessas ações para finalidades próprias ${ }^{477}$, a discussão acerca da viabilidade/legitimidade do registro de candidatura, do diploma e do mandato confere aos titulares (ou pretensos titulares) desses direitos a legitimidade passiva. Tratando-se de cargo de chefia do Executivo, o TSE assentou, a partir da questão de ordem no RCED 703/SC ${ }^{478}$, que não apenas o cabeça de chapa, mas também o Vice, deverão integrar o processo na condição de litisconsortes passivos necessários.

Os dois procedimentos eleitorais legalmente previstos - AIRC e AIJE - contemplam a indicação de um rol de legitimados ativos limitado aos candidatos, partidos políticos e coligações e Ministério Público Eleitoral (arts. $3^{\circ}$ e 22, LC 64/90).

A mesma legitimidade ativa se aplica às representações específicas fundadas no art. 41-A e 73 da Lei 9.504/97, uma vez que tais dispositivos não trazem previsão expressa a respeito e remetem o processamento das ações ao art. 22 da LC 64/90. No entanto, em relação à representação fundada no art. 30-A da Lei 9.504/97, que indica expressamente a propositura por

477. Por exemplo, o partido poderá se apresentar como assistente litisconsorcial do seu candidato na AIRC, os agentes públicos responsáveis pela prática de condutas vedadas pelo art. 73 da Lei 9.504/97 poderão figurar no polo passivo.

478. PROCESSO - RELAÇÃO SUBJETIVA - LITISCONSÓRCIO NECESSÁRIO - CHAPA - GOVERNADOR E VICE-GOVERNADOR - ELEIÇÃO - DIPLOMAS - VÍCIO ABRANGENTE - DEVIDO PROCESSO LEGAL. A existência de litisconsórcio necessário - quando, por disposição de lei ou pela natureza da relação jurídica, o juiz tiver de decidir a lide de modo uniforme para todas as partes - conduz à citação dos que possam ser alcançados pelo pronunciamento judicial. Ocorrência, na impugnação a expedição de diploma, se o vício alegado abrange a situação do titular e do vice. (TSE RCED: 703 SC, Relator: JOSÉ AUGUSTO DELGADO, Data de Julgamento: 21/02/2008, Data de Publicação: DJ - Diário de justiça, Data 24/03/2008, Página 9). 
partido político ou candidato, o TSE firmou jurisprudência no sentido de que a ação pode ser manejada pelo Ministério Público Eleitoral ${ }^{479}$ mas, não, pelo candidato ${ }^{480}$.

O art. 262 do Código Eleitoral e o art. 14, $\$ 10$ da CR/88 são omissos quanto aos legitimados para a propositura do RCED e da AIME. O TSE, por via jurisprudencial, determina a aplicação analógica do rol de legitimados da AIJE, excluindo os cidadãos sob a afirmação de que "não têm legitimidade ad causam os apenas eleitores"

A exclusão dos eleitores do polo ativo das ações eleitorais denota a adoção do modelo de representação adequada, no qual a prerrogativa de agir em defesa do bem jurídico é atribuída a "órgãos ou pessoas jurídicas [...] canalizadores de uma vontade difusa" ou coletiva ${ }^{482}$. A atuação do representante adequado não se dá na qualidade de titular do direito material, mas, sim, de titular do direito de ação. Sob esse aspecto, as ações eleitorais amoldam-se a uma compreensão de processo coletivo que tem sua gênese na década de 1970, no contexto da chamada segunda onda de acesso à justiça ${ }^{483}$. A peculiaridade é que o interesse na conservação de candidaturas, diplomas e mandatos, apesar de ser também da coletividade (ou de parte desta), é tratada como interesse individual do ocupante do polo passivo, enquanto o interesse no impedimento ou cassação daqueles, alocado no polo ativo, é tratado como tradução unívoca do "interesse público" ${ }^{84}$.

479. RECURSO ORDINÁRIO. AÇÃO DE INVESTIGAÇÃO JUDICIAL ELEITORAL (AIJE) COM BASE NO ART. 22 DA LEI COMPLEMENTAR Nº 64/90 E ART. 30-A DA LEI No 9.504/97. IRREGULARIDADES NA ARRECADAÇÃO E GASTOS DE RECURSOS DE CAMPANHA. PRAZO PARA O AJUIZAMENTO. PRAZO DECADENCIAL. INEXISTENNCIA. COMPETÊNCIA. JUIZ AUXILIAR. ABUSO DE PODER POLÍTICO. CONEXÃO. CORREGEDOR. PROPOSITURA. CANDIDATO NÃO ELEITO. POSSIBILIDADE. LEGITIMIDADE ATIVA. MINISTÉRIO PÚBLICO ELEITORAL. POSSIBILIDADE. SANÇÃO APLICÁVEL. NEGATIVA DE OUTORGA DO DIPLOMA OU SUA CASSAÇÃO. ART'. 30-A, § 2o. PROPORCIONALIDADE. PROVIMENTO. [...] 4. O Ministério Público Eleitoral é parte legítima para propor a ação de investigação judicial com base no art. 30-A (RO no 1596/MG, Rei. Min. Joaquim Barbosa, DJ de 16.3.2009). [...] (TSE - RO: 1540 PA, Relator: FELIX FISCHER, Data de Julgamento: 28/04/2009, Data de Publicação: DJE - Diário da Justiça Eletrônico, Data 01/06/2009, Página 25/26/27).

480. Representação. Art. 30-A da Lei no 9.504/97. Candidato. Ilegitimidade ativa. [...] 2. O art. 30-A da Lei $n^{\circ} 9.504 / 97$ estabelece legitimidade para a propositura de representação prevista nessa disposição legal apenas a partido político e coligação, não se referindo, portanto, a candidato. $3 . \mathrm{O} \S 1^{\circ}$ do art. 30-A da Lei das Eleições - ao dispor que, para a apuração das condutas, será observado o procedimento do art. 22 da Lei Complementar no 64/90 - refere-se, tão-somente, ao rito, não afastando, portanto, a regra de legitimidade específica, expressamente estabelecida no caput do mencionado artigo. Recurso ordinário desprovido. (TSE - RO: 1498 ES, Relator: ARNALDO VERSIANI LEITE SOARES, Data de Julgamento: 19/03/2009, Data de Publicação: DJE - Diário da Justiça Eletrônico, Data 03/04/2009, Página 42).

481. BRASIL. Tribunal Superior Eleitoral. Recurso Especial Eleitoral n. 11835, Relator Min. Torquato Lorena Jardim. Acórdão de 09 jun. 1994. Publicado no Diário de Justiça em 29 jul 1994, p. 18429. In: Revista de Jurisprudência do TSE, v. 6, tomo 3, p. 132.

482. MACIEL JÚNIOR, Vicente de Paula. Teoria das ações coletivas: as ações coletivas como ações temáticas. São Paulo: LTr, 2006, p. 157.

483. CAPPELLETTI, Mauro; GARTH, Bryant. Acesso à justiça. Tradução de Ellen Gracie Northfleet. Porto Alegre: Sérgio Antônio Fabris Editor, 1988.

484. O presente artigo não se concentra no problema da exclusão do eleitor das ações eleitorais. Não se pode deixar, contudo, de registrar que o enfrentamento desse problema foi um dos objetivos específicos que motivaram a proposta da ação temática eleitoral. $\mathrm{Na}$ adaptação do modelo da ação temática ao âmbito eleitoral, a pesquisa contou com premissas extraídas dos estudos de Vicenzo Vigoritti (VIGORITI, Vincenzo. Interessi collettivi e processo: la legitimazione ad agire. Milano: Giuffrè, 1979), Manuel Castells (CASTELLS, 


\subsection{Pedido}

A noção de pedido é comumente associada àquilo que se pleiteia em juízo. Nas palavras de Alexandre Freitas Câmara,"pedido é o meio de declaração da vontade de se obter determinado resultado em juízo, ou, em outros termos, manifestação processual da pretensão" ${ }^{\text {"85. }}$.

No entanto, mesmo o Direito Processual Civil reconhece a possibilidade de pedidos implicitos $^{486}$, ou seja, pretensões presumidas, porque não manifestadas, que deverão ser objeto de julgamento. Nas ações eleitorais destinadas à apuração de ilícitos (AIJE, AIME e representaçóes específicas), as consequências jurídicas do reconhecimento destes podem ser pronunciadas de ofício pelo órgão julgador, independentemente de formulação expressa pelo autor. Por exemplo, ainda que o autor de uma representação fundada no art. 73 da Lei 9.504/97 limite-se a pleitear a aplicação de multa ao agente público que nela incorreu, a decisão condenatória poderá abarcar a cassação do registro ou diploma, uma vez prevista essa sanção no $\$ 5^{\circ}$ do artigo citado ${ }^{487}$.

Diante disso, mostra-se pertinente conceituar pedido como "a consequência jurídica (eficácia) que se pretende ver realizada pela atividade jurisdicional” ${ }^{888}$, admitindo-se o pedido implícito como "aquele que, embora não explicitado no instrumento da postulação, compóe o objeto litigioso do processo (mérito) em razão de determinação legal" ${ }^{889}$. Assim, pode-se satisfatoriamente associar a ideia de pedido às providências jurídicas que terão lugar em caso de reconhecimento da causa de pedir deduzida nas ações eleitorais.

O presente artigo concentra-se nas providências jurídicas que repercutem sobre o registro de candidatura, o diploma e o mandato, que são direitos progressivamente adquiríveis ao longo do processo eleitoral. As açóes eleitorais que os discutem encampam a pretensão de que seja impedida a aquisição desses direitos ou, então, de que sejam estes extintos. Mas a legislação vale-se de terminologia variada: 1) AIRC: negativa/cancelamento do registro e declaração de nulidade do diploma (art. 15, LC 64/90); 2) AIJE e representação por captação ilícita de sufrágio e por conduta vedada: cassação do registro/diploma (art. 22, XIV, LC 64/90; arts. 41-A e 73, §5, Lei 9.504/97); 3) Representação por arrecadação ou gasto ilícito de recursos:

Manuel. A sociedade em rede. 14a reimpressão com novo prefácio. São Paulo: Paz e Terra, 2011. (A era da informação. Economia, sociedade e cultura ;1)), Rodolfo Viana Pereira (PEREIRA, Rodolfo Viana. Tutela coletiva no direito eleitoral: controle social e fiscalização das eleições. Rio de Janeiro: Lumen Juris, 2008) e Edilene Lôbo (LÔBO, Edilene. A inclusão do cidadão no processo eleitoral. Belo Horizonte: Del Rey, 2010) para conceber um modelo de controle da legitimidade das eleições no qual, superados entraves materiais dos autos físicos, as ações judiciais eleitorais possam se abrir à participação dos principais interessados: os cidadãos.

485. CÂMARA, Alexandre Freitas. Lições de direito processual civil: volume 1, p. 263.

486. No CPC/2015, são previstas como pedidos implícitos a condenação ao pagamento de juros legais e a incidência da correção monetária $\left(\operatorname{art} .332, \$ 1^{\circ}\right)$ e a condenação ao pagamento de prestações vincendas nas obrigações periódicas (art. 323).

487. Lei 9.504/97, art. 73, §5\%:"Nos casos de descumprimento do disposto nos incisos do caput e no $\S 10$, sem prejuízo do disposto no $₫ 4^{\circ}$, o candidato beneficiado, agente público ou não, ficará sujeito à cassação do registro ou do diploma".

488. DIDIER JR. Fredie. Curso de direito processual civil: introdução ao direito processual civil, parte geral e processo de conhecimento. 17. ed. rev. ampl. e atual. Salvador: Jus Podivum, 2015, p. 565.

489. DIDIER JR. Fredie. Curso de direito processual civil: introdução ao direito processual civil, parte geral e processo de conhecimento, p. 590. 
negativa/cassação de diploma (art. 30-A, §2 lei 9.504/97). Em relação à AIME e ao RCED, não há previsão normativa expressa acerca do pedido, inferindo-se da própria epígrafe de tais ações que a primeira tem por objeto a desconstituição do mandato e, a segunda, a anulação do diploma.

A despeito da variação dos termos, a eficácia de todas as providências é similar: o alijamento do réu do processo eleitoral, independentemente da etapa em que este se encontre (registro de candidatura, eleição, diplomação). A par disso, pode-se distinguir que, no caso da AIRC e do RCED, esse alijamento decorre da ausência de requisitos para viabilizar a candidatura ou a diplomação, enquanto nos demais casos constitui ele uma sanção pela prática de ato ilícito. No entanto, essa distinção diz mais a respeito da causa de pedir dessas ações do que do pedido.

\subsection{Causa de pedir}

A causa de pedir corresponde à narrativa que confere suporte ao pedido. Segundo o art. 319, III, do CPC/2015, a petição inicial deve indicar "o fato e os fundamentos jurídicos do pedido". Tomada essa previsão, cabe ao autor declinar tanto o relato dos fatos quanto a configuração jurídica a esses atribuída, o que permite, em seu conjunto, obter a providência judicial visada. Trata-se aqui da adoção da teoria da substanciação, segundo a qual "não basta a indicação da relação jurídica, efeito do fato jurídico, sem que se indique qual o fato jurídico que lhe deu causa" ${ }^{\prime 490}$.

Desse modo, o suporte do pedido depende da enunciação da causa de pedir fática (remota) e da causa de pedir jurídica (próxima). Para as ações eleitorais, nem sempre é clara essa previsão.

No que se refere à AIRC, prevalece o entendimento de que a pretensão de indeferimento do registro de candidatura tem como causa de pedir a ausência de condição de elegibilidade ou a incidência de causa de inelegibilidade previamente configurada. Sendo assim, as situações que podem compor a causa de pedir fática serão localizadas na CR/88, na LC 64/90 e na Lei 9.504/97, nos dispositivos que tratam desses requisitos da candidatura. Tais situaçóes devem ser pré-constituídas, o que caracteriza a AIRC como uma ação declaratória ${ }^{491}$, e, não, condenatória, estando excluída de seu âmbito a apuração de condutas ilícitas ${ }^{492}$.

Porém, Adriano Soares da Costa sustenta que, uma vez que "LC no 64/90 não impôs nenhuma causa de limitação da cognição dos fatos alegados nessa ação, nem tampouco pres-

490. DIDIER JR. Fredie. Curso de direito processual civil: introdução ao direito processual civil, parte geral e processo de conhecimento, p. 552.

491. A natureza declaratória é inferida do art. 15 da LC 64/90, segundo o qual: “Transitada em julgado ou publicada a decisão proferida por órgão colegiado que declarar a inelegibilidade do candidato, ser-lhe-á negado registro, ou cancelado, se já tiver sido feito, ou declarado nulo o diploma, se já expedido."

492. RECURSO ELEITORAL. REGISTRO DE CANDIDATURA. [...] OBJETIVO ESPECÍFICO. CONDIÇÕES CONSTITUCIONAIS E LEGAIS DE ELEGIBILIDADE. INEXISTÊNCIA DE INELEGIBILIDADE. AFERIÇÃO. CAPTAÇÃO DE SUFRÁGIO. AÇÃO ESPECÍFICA. PROVIMENTO. [...] 3. O objeto do processo de registro de candidatura é específico: averiguar a presença das condições constitucionais e legais de elegibilidade e a inexistência das causas de inelegibilidade. Portanto, em sede de registro de candidatura não se apura abuso nem se declara inelegibilidade, ainda que sob o amparo dos princípios da economia processual e da instrumentalidade das formas. 4. A lei indica que a ação de investigação judicial é o meio próprio para apurar uso indevido, desvio ou abuso do poder econômico ou do poder de autoridade, ou utilização indevida de veículos ou meios de comunicação social, em benefício de candidato ou de partido político, não se podendo fazê-lo na ação de impugnação de registro de candidatura. (TRE-TO - RE: 458 TO, Relator: ANTÔNIO FÉLIX GONÇALVES, Data de Julgamento: 03/09/2008, Data de Publicação: PSESS - Publicado em Sessão, Data 3/9/2008) 
creveu qualquer espécie de poda dos meios probatórios", a AIRC pode ser manejada com fundamento em abuso de poder econômico, abuso de poder político, uso indevido dos meios de comunicação social, fraude ou corrupção ocorridos antes do requerimento de registro de candidatura ${ }^{493}$. Embora inegável que Costa se ampara na literalidade do art. $3^{\circ}$ da LC 64/90, que é omisos quanto a causa de pedir da AIRC, seu argumento desconsidera outros aspectos - em especial a impossibilidade de que o indeferimento do registro de candidatura possa se amparar em causa de inelegibilidade superveniente ao requerimento deste $e^{494}$, o que tornaria inócua a condenação à inelegibilidade proferida no bojo de AIRC.

Em relação à causa de pedir do RCED, a polêmica mais intensa versou sobre a redação do inciso IV do art. 262 do Código Eleitoral, que previa o cabimento daquele contra a "concessão ou denegação do diploma em manifesta contradição com a prova dos autos, nas hipóteses do Código Eleitoral, art. 222 e da Lei n. 9.504/1997, art. 41-A”. Essa hipótese de cabimento era por vezes manejada para fins de rediscussão de abuso de poder econômico e captação ilícita de sufrágio já apurados em AIJE ${ }^{495}$. O TSE, em controle incidental de constitucionalidade, declarou o citado inciso inconstitucional. No entendimento do tribunal, a Constituição teria estipulado a AIME como "único veículo pelo qual é possível impugnar o mandato já reconhecido pela Justiça”, reconhecimento este que se dá com a diplomação, e a manutenção de RCED para o mesmo fim era incompatível com essa sistemática ${ }^{496}$. Com o advento da Lei $\mathrm{n}$. 12.891/2013, os incisos do art. 262 do Código Eleitoral foram revogados e a nova redação

493. COSTA, Adriano Soares da. Instituições de direito eleitoral. 9. ed. rev. ampl. e atual. Belo Horizonte: Fórum, 2013, p. 310.

494. É o que se extrai do $§ 10^{\circ}$ do art. 11 da Lei 9.504/97, segundo o qual “As condições de elegibilidade e as causas de inelegibilidade devem ser aferidas no momento da formalização do pedido de registro da candidatura, ressalvadas as alterações, fáticas ou jurídicas, supervenientes ao registro que afastem a inelegibilidade."

495. Cabe assinalar que, mesmo diante dessa redação, uma interpretação sistêmica era adequada para repelir esse manejo. Bastava perceceber que o inciso IV do art. 262 do Código Eleitoral era, todo ele, anterior à alteração promovida pela LC 135/2010 nas consequências da condenação em AIJE. Se foi somente a partir daí que a AIJE passou a comportar sanção contra o candidato após a eleição, justificava-se a previsão do RCED para desconstituir o diploma caso a condenação na AIJE fosse posterior à eleição. Ou seja, o inciso em comento nada mais significava que a possibilidade de exibição de prova pré-constituída nos autos da AIJE, na qual condenado o réu, para fins de cassar seu diploma. Porém, a partir do momento em que a própria jurisprudência do TSE, a pretexto de assegurar o contraditório, decidiu que o RCED comportava a produção ampla de prova dos ilícitos referidos no inciso IV é que se teve a sobreposição de ações com a mesma finalidade, passando o RCED a funcionar como uma oportunidade de rejulgamento da matéria da AIJE, mesmo quando julgada esta improcedente ou ainda em tramitação.

496. "RECURSO CONTRA EXPEDIÇÃO DE DIPLOMA. DEPUTADO FEDERAL. CÓDIGO ELEITORAL. ART. 262, IV. INCONSTITUCIONALIDADE. RECEBIMENTO, AÇÃO DE IMPUGNAÇÃO DE MANDATO ELETIVO. PRINCÍPIO DA SEGURANÇA JURÍDICA. FUNGIBILIDADE. TRIBUNAL REGIONAL ELEITORAL. COMPETÊNCIA DECLINADA. QUESTÃO DE ORDEM. VISTA. PROCURADORIA GERAL ELEITORAL. REJEIÇÃO. 1. A Constituição Federal de 1988 estabeleceu, no art. 14, §10, qual é o único veículo pelo qual é possível impugnar o mandato já reconhecido pela Justiça Eleitoral. 2. Desse modo, o inciso IV do art. 262 do Código Eleitoral, no que diz respeito à redação original do dispositivo, não foi recepcionado pela Constituição brasileira e, quanto à parte final, denota incompatibilidade com a disciplina constitucional. [...] 4. Recurso contra expedição de diploma recebido como ação de impugnação de mandato eletivo em razão do princípio da segurança jurídica e remetido ao Tribunal Regional Eleitoral, órgão competente para o seu julgamento." (Recurso Contra Expedição de Diploma n. 884.2011.6.18.000, Relator Min. Dias Toffoli. Acórdão de 12 set. 2013. Publicado no Diário de Justiça Eletrônico em 12 nov. 2013, n. 216, página 54-55). 
do dispositivo legal passou a restringir o manejo do RCED apenas às hipóteses de inelegibilidade infraconstitucional superveniente, inelegibilidade constitucional e ausência de condição de inelegibilidade ${ }^{497}$.

Passando ao exame das ações que versam sobre ilícitos eleitorais, a problemática em torno da causa de pedir se acentua. Exceto pela captação ilícita de sufrágio, pelas condutas vedadas e pelo abuso de autoridade (aquele previsto no art. 74 da Lei 9.504/97), a lei não se ocupou em tipificar as condutas ilícitas que configurariam a causa de pedir fática mas, sim, optou por adotar conceitos jurídicos indeterminados, acompanhados de poucas diretrizes para sua concreção. A maioria desses conceitos tem por denominador comum a noção de abuso de poder, que, segundo José Jairo Gomes:

[...] deve ser interpretada como a concretização de ações - ou omissões - com vistas a influenciar ou determinar opções e comportamentos alheios; tais ações denotam o mau uso dos recursos detidos, controlados pelo beneficiário ou a ele disponibilizados. As condutas levadas a cabo não são razoáveis ne normais à vista do contexto em que ocorrem, revelando existir exorbitância, desbordamento ou excesso por parte do agente. ${ }^{498}$

Abre-se aqui um feixe de possibilidades para a sobreposição de ações, versando sobre distintas causa de pedir jurídicas, embora ostentem a mesma causa de pedir fática. Ou seja, varia-se a configuração jurídica empregada a um mesmo contexto fático. Suponha-se, por exemplo, uma "compra de votos" de diversos eleitores, perpetrada por candidato à reeleição, por meio da doação de cestas básicas adquiridas pelo Município para distribuição em um programa social. A mesma conduta pode, hipoteticamente, se amoldar à captação ilícita de sufrágio, às condutas vedadas pelos incisos I e IV do art. 73 da Lei n. 9.504/1997, ao abuso de poder político e ao abuso de poder econômico. Isso significa a possibilidade - ao menos - de três representações específicas (fundadas no art. 41-A e nos citados incisos do art. 73, todos da Lei 9.504/97), duas AIJEs (por abuso de poder econômico e de poder político) e duas AIMEs (por abuso de poder econômico e por corrupção).

\subsection{Focos de problematização da identidade entre ações eleitorais}

Feita essa breve exposição sobre os elementos das ações eleitorais, é possível estabelecer alguns focos para a problematização da identidade entre as ações eleitorais.

A opção pelo modelo de representação adequada repercute diretamente na abordagem do tema do presente artigo. Afinal, os legitimados não defendem interesse próprio (caso do Ministério Público Eleitoral) ou, ainda que o façam (partidos, coligaçóes e candidatos), concorrem com interesses de terceiros (eleitores e, de modo mais generalizado, a população). Além disso, "a legitimação ativa nas ações coletivas é [...] concorrente e disjuntiva [...] sendo que qualquer legitimado pode propor sozinho a ação, sem necessidade de autorização ou

497. "O recurso contra expedição de diploma caberá somente nos casos de inelegibilidade superveniente ou de natureza constitucional e de falta de condição de elegibilidade." (BRASIL. Código Eleitoral (1965). Lei n. 4.737, de 15 de julho de 1965 , art. 262.).

498. GOMES, José Jairo. Direito eleitoral. 11. ed. rev. atual. e a ampl.. São Paulo: Atlas. 2015, p. 258. 
comunicação aos demais" ${ }^{\prime 499}$. Diante disso, até que ponto o preenchimento do polo ativo por um diferente legitimado pode ser considerado relevante para distinguir ações que tenham mesmo pedido e causa de pedir? No caso da AIRC, há norma expressa no sentido de que "a impugnação, por parte do candidato, partido político ou coligação, não impede a ação do Ministério Público no mesmo sentido" (art. 3º, §1º, LC 64/90). Quanto às demais ações, nada se dispõe. Surge daí o desafio para o equacionamento da atuação simultânea de mais de um legitimado ${ }^{500}$.

Quanto ao pedido, nota-se que a variabilidade terminológica empregada pela legislação não parece fornecer um critério robusto o suficiente para se afastar a identidade de ações. Supondo-se uma AIJE ajuizada por abuso de poder econômico, em face de determinados fatos e entre determinadas partes, tudo a se repetir em posterior AIME, será possível afastar a litispendência na segunda ação ao argumento de que nesta se pede a cassação de mandato e, naquela, se pedia a cassação de registro ou diploma? Essa indagação coloca em dúvida a afirmação José Jairo Gomes no sentido de que "posto que idênticos os fatos, [...] se na AIJE se pedir tão só cassação de registro e inelegibilidade e na AIME se pleitear a cassação de mandato[,] [e]stá claro que a diversidade de pedidos afasta a litispendência e a coisa julgada"501.

Por fim, em relação à causa de pedir, a situação em que um mesmo fato enseja diversas configurações jurídicas tem sido o ponto mais sensível para o julgamento de múltiplas ações

499. LASCALA, Maria Carolina Florentino; COSTA, Yvete Flávio da. A litispendência nas ações coletivas. In: Revista electronica do curso de Direito da UFSM, v. 5, n. 3 (2010). Disponível em: <http://cascavel. ufsm.br/revistas/ojs-2.2.2/index.php/revistadireito/article/view/7057\#.VsMusJMrKi4>. Acesso em: 10 fev. 2016.

500. A complexidade da questão se acentua tendo em vista que, ao contrário do que ocorre com outras ações coletivas, a população diretamente afetada pela decisão judicial - ou seja, eleitores e, mais amplamente, governados e representados - não tem tido reconhecido direito de participar das ações eleitorais, ainda que na posição de assistente, o que compromete o controle da qualidade da atuação do representante adequado. Como posto, porém, essa questão não será abordada no presente artigo.

501. GOMES, José Jairo. Direito eleitoral. 11. ed. rev. atual. e a ampl.. São Paulo: Atlas. 2015, p. 548. Há dúvida se essa afirmação, embora constando de edição da obra de 2015, ainda levaria em conta a redação dos incisos XIV e XV do art. 22 da LC 64/90 anterior à alteração promovida pela LC 135/2010. Isso porque na anterior redação, o julgamento de procedência da AIJE após a eleição era incapaz de acarretar a cassação do registro ou do diploma, havendo necessidade de instauração de AIME para a finalidade de promover a cassação do mandato. A respeito, vale conferir o seguinte julgado do TRE/RJ: "Ação de Impugnação de Mandato Eletivo. Ação de Investigação Judicial Eleitoral. Litispendência. Possibilidade. I - Com o advento da Lei Complementar n. ${ }^{\circ}$ 135/10, que alterou a Lei Complementar n. ${ }^{\circ} 64 / 90$, passou a ser possível a formação de litispendência entre AIJE e AIME, naquilo que for causa de pedir comum a ambas as ações. II - Ainda que não tenha sido alvitrada a possibilidade de litispendência por nenhuma das partes, tal matéria é passível de conhecimento de ofício em qualquer tempo e grau de jurisdição, conforme a previsão do parágrafo $3^{\circ}$ do artigo 267 do Código de Processo Civil, bem assim do natural efeito translativo deste recurso. III - Assim é que a possibilidade de formação da litispendência entre as ações eleitorais não impede que em determinados casos os mesmos fatos sejam examinados sob diferentes óticas. No entanto, a simples leitura do artigo 22 da Lei Complementar n. ${ }^{\circ}$ 64/90 e do artigo $14, \S 10^{\circ}$, da Constituição revela identidade da hipótese de cabimento referente ao abuso de poder econômico. E este é exatamente o caso em apreço, uma vez que a causa de pedir dos autos não abrange a corrupção ou a fraude eleitorais contidas no artigo $14, \S 10^{\circ}$, da Constituição, limitando-se o autor a narrar a ocorrência de abuso de poder econômico e político, sendo este último sequer caso de manejo da Ação de Impugnação de Mandato Eletivo. IV - Recurso Eleitoral prejudicado por versar sobre os mesmos fatos constantes do Recurso Eleitoral n. ${ }^{\circ}$ 534-66. Extinção do processo sem resolução do mérito, na forma do artigo 267, inciso V, do Código de Processo Civil." (TRE-RJ - RE: 258 RJ, Relator: FABIO UCHOA PINTO DE MIRANDA MONTENEGRO, Data de Julgamento: 02/06/2014, Data de Publicação: DJERJ - Diário da Justiça Eletrônico do TRE-RJ, Tomo 123, Data 11/06/2014, Página 14/21) 
eleitorais. Isso se deve, em parte, a um suposto desdobramento da teoria da substanciação que pode ser assim explicado:

[...] não é necessário que o autor qualifique juridicamente seu pedido, bastando fornecer, com a maior exatidão possível, a origem dos fatos que dão fundamento ao seu pedido. [...] Eventuais qualificações jurídicas constantes da petição inicial devem ser, para o nosso sistema, entendidas como mera propostas de qualificação. Não são essenciais e, de resto, não são vinculantes para o magistrado. $\mathrm{O}$ réu deve se defender dos fatos constitutivos do direito do autor. ${ }^{502}$

Embora prestigiada, essa leitura parece subverter o sentido da teoria da substanciação. Tal teoria compareceu para conferir delimitação mais precisa ao objeto das ações, de modo que não bastasse ao autor, como quer a teoria da individuação, indicar a qualificação jurídica da qual pretende extrair efeitos, deixando em aberto quais fatos poderiam conferir suporte à procedência do pedido. Mas daí não parece decorrer necessariamente - sobretudo em face da redação do art. 319, III, CPC/2015 - que a configuração jurídica a ser dada aos fatos possa ser desprezada como elemento delimitador da causa de pedir.

Nas ações eleitorais, exatamente porque os mesmos fatos podem merecer variadas configurações jurídicas, acentua-se a importância da enunciação clara da causa de pedir jurídica. Esse aspecto, muitas vezes negligenciado em uma leitura pro societatis do Direito Eleitoral - na qual a técnica processual é tomada como entrave à busca da verdade real e, não, como desdobramento do devido processo legal -, é exigência da dimensão de não surpresa do contraditório ${ }^{503}$, uma vez que o réu poderá se defender não apenas pela contraposição aos fatos imputados pelo autor mas, também, pela contraposição à conformação jurídica dada a tais fatos.

Colhidos esses aspectos problematizantes, cumpre examinar como, na ausência de sistematização teórica e técnica de um Direito Processual Eleitoral, a jurisprudência e, mais recentemente, a legislação vêm conduzindo o tema da identidade entre ações eleitorais.

\section{Um efeito colateral e duas vias de tratamento}

A identidade entre açóes eleitorais é um problema cuja complexidade acompanha a intensidade das alterações legislativas que, ao buscar possibilitar tutela mais efetiva dos bens jurídicos relacionados à higidez das eleições, também fazem com que as ações eleitorais se tangenciem de modo cada vez mais intrincado. Pode-se dizer, então, que se trata de um efeito colateral do avanço do Direito Eleitoral sobre a política, decorrente, sobretudo, do modo fragmentado pelo qual aquele ocorre.

502. BUENO, Cassio Scarpinella. Curso sistematizado de direito processual civil: teoria geral do direito processual civil, p. 417.

503. Segundo Dierle Nunes,"o contraditório constitui um[a] verdadeira garantia de não surpresa, que impõe ao juiz o dever de provocar o debate acerca de todas as questões, inclusive as de conhecimento oficioso, impedindo que em solitária onipotênciá aplique normas ou embase a decisão sobre fatos completamente estranhos à dialética defensiva de uma ou de ambas as partes" (NUNES, Dierle José Coelho. Processo jurisdicional democrático. Curitiba: Juruá, 2008, p. 229.). 
Por isso, antes de analisar o tratamento que a jurisprudência e a legislação oferecem para combater esse efeito colateral, é preciso ter clareza a respeito dos marcos temporais que propiciaram o surgimento e o aguçamento do problema da identidade de ações.

1) Até 1988, o RCED era, por excelência, o mecanismo de controle da legitimidade das eleições. O Código Eleitoral tinha uma sistemática simples, porém consistente: o RCED podia ser manejado diretamente, nos casos de inelegibilidade, incompatibilidade, errônea interpretação da lei quanto à aplicação do sistema proporcional ou erro de direito ou de fato na apuração final, ou com amparo em provas colhidas em investigação eleitoral prevista no art. 237 do Código Eleitoral ${ }^{504}$. Adriano Soares da Costa explica que essa investigação, a cargo do Corregedor (Geral ou Regional) Eleitoral, possuía "natureza pré-processual de inquérito, de cunho administrativo, que servia para produzir as provas necessárias para posterior manejo de recurso contra a diplomação" ${ }^{505}$. É nesse contexto que faz completo sentido a redação do inciso IV do art. 262, ao estipular o cabimento do RCED contra "concessão ou denegação do diploma, em manifesta contradição com a prova dos autos, na hipótese do art. 222": os autos referidos são o da investigação eleitoral destinada a apurar falsidade, fraude, coação, abuso de poder econômico, abuso de poder de autoridade e emprego de propaganda e captação de sufrágio vedados por lei. Além disso, o art. 97 trata da impugnação ao registro de candidatura, por simples manifestação de candidato, partido político ou eleitor.

2) A AIME, criada em 1988 pela Constituição, difere do RCED por se tratar de "ação judicial autônoma contra abuso de poder econômico, corrupção ou fraude, após exaurido o processo eleitoral, com o ato de diplomação, e sem ter correlatividade recursória a qualquer procedimento anteriormente instaurado" ${ }^{\prime 50}$.

3) Em 1990, a LC 64 trata da impugnação ao registro de candidatura que, procedimentalizada em contraditório, passa a ter reconhecida sua natureza judicial (AIRC). A mesma lei também cria a AIJE, ação judicial que substitui a impugnação eleitoral do Código Eleitoral. Com isso, a remissão do inciso IV do art. 262, à "prova dos autos", ganha nova conotação, fazendo surgir a questão sobre a reiteração de RCED com mesma causa de pedir de anterior AIJE. Por outro lado, é expresso nos incisos XIV e XV do art. 22 da LC 64/90 que a procedência da AIJE somente conduziria à cassação do registro de candidatura, desde que julgada até a eleição; caso contrário, os autos da AIJE subsidiariam a propositura de AIME, para fins de cassação do mandato.

504. Código Eleitoral, art. 237:"A interferência do poder econômico e o desvio ou abuso do poder de autoridade, em desfavor da liberdade do voto, serão coibidos e punidos. [...] $₫ 2^{\circ}$ Qualquer eleitor ou partido político poderá se dirigir ao Corregedor Geral ou Regional, relatando fatos e indicando provas, e pedir abertura de investigação para apurar uso indevido do poder econômico, desvio ou abuso do poder de autoridade, em benefício de candidato ou de partido político."

505. COSTA, Adriano Soares da. Instituições de direito eleitoral, p. 343.

506. RIBEIRO, Fávila. Pressupostos constitucionais do direito eleitoral: no caminho da sociedade participativa. Porto Alegre: Sergio Antonio Fabris Editor, 1990, p. 105. 
4) Em 1999, a Lei 9.840, de iniciativa popular, tipificou a captação ilícita de sufrágio ao introduzir o art. 41-A na Lei 9.504/97, remetendo a apuração desse ilícito ao procedimento da AIJE. Aquela lei também conectou o RCED ao novo ilícito eleitoral, porque conferiu nova redação ao inciso IV do art. 262 do Código Eleitoral para abarcar a concessão/denegação de diploma contrária à prova dos autos em caso de captação ilícita de sufrágio. Foi também a Lei 9.840/99 que inseriu a sanção de cassação do registro ou do diploma para as condutas vedadas pelo art. 73 da Lei 9.504/97, que, na redação original dessa lei, ensejavam apenas multa.

5) Em 2006, a arrecadação e o gasto ilícito de recursos de campanha são tipificados como ilícitos eleitorais aptos a subsidiar a propositura de AIJE, por força da Lei 11.300, que introduziu o art. 30-A na Lei 9.504/97.

6) Em 2010, a LC 135 altera o inciso XIV e revoga o inciso XV do art. 22 da LC 64/90, passando a prever que a procedência da AIJE conduza à cassação de registro ou diploma, sem condicionamento à data do julgamento. Com isso, deixa de ser necessário ajuizar a AIME para a finalidade de retirar o condenado do cargo eletivo.

7) Em 2013, o alcance do RCED, que vinha sendo alargado, é subitamente reduzido pela Lei 12.891, passando a ser cabível, apenas, em caso de inelegibilidade superveniente, inelegibilidade constitucional ou ausência de condição de elegibilidade. Essa redação será aplicada a partir do pleito de 2016 e ressignifica a função sistêmica do RCED, aproximando-a daquela da AIRC, como procedimento destinado à aferição objetiva de situações pré-constituídas (em relação ao momento de propositura daquele).

Esse breve apanhado permite compreender fatores que provocaram o surgimento de questionamentos sobre a repetição de ações no âmbito da Justiça Eleitoral. Especialmente a partir da criação das representaçóes específicas e da possibilidade de que a AIJE conduzisse à cassação do diploma, ocorre uma interpenetração das causas de pedir entre ações de finalidades similares. Passa-se a examinar os tratamentos oferecidos ao problema: o, primeiro, pelo TSE e, o segundo, pela recente Minirreforma Eleitoral (Lei 13.165/2015). 


\subsection{O posicionamento do TSE sobre litispendência e coisa julgada}

A primeira abordagem da questão pelo TSE seguiu a diretriz do CPC, exigindo a tríplice identidade - partes, causa de pedir e pedido - para que fosse reconhecida a litispendência ou a coisa julgada entre açóes eleitorais, capaz de conduzir à extinção da segunda demanda proposta. Na década de 2000, consolidou-se jurisprudência no sentido de que não existe litispendência ou coisa julgada entre as diversas ações eleitorais, uma vez que estas possuem causa de pedir própria ${ }^{507}$ e objetivos distintos ${ }^{508}$.

Essa linha jurisprudencial, contudo, baseia-se em um afastamento apriorístico da litispendência e da coisa julgada. Tomaram-se as ações em tese, desconsiderando-se que a aferição da identidade de ações, na sistemática do CPC, exige o cotejo entre os elementos de duas demandas concretamente ajuizadas para, em caso positivo, extinguir a segunda ação sem resolução do mérito ${ }^{509}$. Ignorou-se, portanto, que, de acordo com a técnica processual, a distinção entre espécies processuais previstas no ordenamento nada diz acerca da possibilidade de que, em um caso concreto, uma venha a ser manejada como sucedâneo desautorizado da outra.

Mesmo dentro dessa vertente de rejeição da ocorrência de litispendência entre ações em tese, a partir de 2010, com a ampliação do alcance da AIJE, tornou-se pouco subsistente a defesa de que as cassaçóes de registro, de diploma ou de mandato constituíssem "objetivos distintos" aptos a afastar a tríplice identidade entre os elementos das açóes eleitorais. Afinal, a definição da providência cabível - cassação do registro de candidatura, do diploma ou do mandato - passou a ser meramente circunstancial, definindo-se em função do status

\section{RECURSO ESPECIAL ELEITORAL. RECURSO CONTRA EXPEDICCÃO DE DIPLOMA. AUSÊNCIA DE LITISPENDÊNCIA COM AÇÃO DE INVESTIGÁÇÃO DE MANDATO ELETIVO OU AÇÃO DE INVESTIGAÇÃO JUDICIAL ELEITORÁL. AÇÕES AUTÔNOMAS COM CAUSAS DE PEDIR PRÓPRIAS. DISSÍDIO JURISPRUDENCIAL CONFIGURADO. PROVIMENTO. 1. Dissídio jurisprudencial configurado. Aresto regional que, acol- hendo preliminar de litispendência, extinguiu o processo, sem resolução de mérito, haja vista o RCED ter os fatos e as conseqüências idênticos aos de uma AIME, e de uma AIJE, ambas julgadas improcedentes. 2. A jurisprudência do TSE é de que a Ação de Impugnação de Mandato Eletivo, a Ação de Investigação Judicial Eleitoral e o Recurso Contra Expedição de Diploma são instrumentos processuais autônomos com causa de pedir própria. 3. A jurisprudência da Corte caminha no sentido de que quando o RCED baseia-se nos mesmos fatos de uma AIJE, julgada procedente ou não, o trânsito em julgado desta não é oponível ao trâmite do RCED. 4. Recurso especial eleitoral provido para, rejeitando a preliminar de litispendência, determinar o retorno dos autos ao TRE/RJ, que deverá apreciar o recurso contra expedição de diploma como entender de direito. (TSE - RESPE: 28015 RJ, Relator: JOSÉ AUGUSTO DELGÁDO, Data de Julgamento: 25/03/2008, Data de Publicação: DJ - Diário da Justiça, Data 30/04/2008, Página 5)}

508 Agravo regimental. Recurso especial. Ação de impugnação de mandato eletivo. Alegação. Litispendência. Ações de investigação judicial eleitoral. Não-configuração. Ausência. Identidade. Partes, pedido e causa de pedir. Finalidades diversas. Precedentes. Violação. Arts. 267, V, e 301, $\$ \$ 1^{\circ}$ e $2^{\circ}$, do Código de Processo Civil. Não-caracterização. Decisão agravada. Fundamentos não afastados. 1. Não há litispendência entre ação de impugnação de mandato eletivo e investigação judicial eleitoral, uma vez que tais ações têm fundamentos próprios, bem como possuem objetivos diversos: enquanto a AIME visa a cassação do mandato eletivo, a AIJE busca a declaração de inelegibilidade dos investigados e/ou a cassação do registro do candidato beneficiado. 2. Nega-se provimento a agravo regimental que não afasta os fundamentos da decisão impugnada. (TSE - ARESPE: 26314 CE, Relator: CARLOS EDUARDO CAPUTO BASTOS, Data de Julgamento: 06/03/2007, Data de Publicação: DJ - Diário de justiça, Data 22/3/2007, Página 142)

509 Extrai-se do CPC/2015: “art. 337, \$1 Verifica-se a litispendência ou a coisa julgada quando se reproduz ação anteriormente ajuizada. $\$ 2^{\circ}$ Uma ação é idêntica a outra quando possui as mesmas partes, a mesma causa de pedir e o mesmo pedido. $\$ 3^{\circ}$ Há litispendência quando se repete ação que está em curso. $\$ 4^{\circ}$ Há coisa julgada quando se repete ação que já foi decidida por decisão transitada em julgado." 
do cidadão em cada estágio temporal do período eleitoral. $\mathrm{Na}$ nova sistemática, tanto por AIJE, AIME ou RCED passou a ser possível obter medida eficaz para prevenir ou reparar a constituição ilegítima de governos e parlamentos, o que força o abandono de uma distinção puramente literal entre os pedidos das ações eleitorais.

Nesse contexto, principia uma alteração de direcionamento da jurisprudência que se faz sentir, primeiramente, em relação ao inciso IV do art. 262 do Código Eleitoral. Conforme já mencionado, em 2013 o dispositivo foi declarado inconstitucional pelo TSE, por conflitar com o objeto da AIME e, poucos meses depois, foi revogado.

Mas a modificação de entendimento mais interessante para a temática do presente artigo diz respeito a recentes julgados do TSE que sinalizam a preocupação em estabelecer uma nova linha de aplicação dos institutos da litispendência e da coisa julgada entre as ações eleitorais. Assim, o TSE passa a admitir que a aferição da identidade de ações deva se dar no caso concreto e, não, entre as ações em tese.

Contudo, constata-se a indefinição da diretriz teórica a ser adotada. Em um primeiro caso, a coisa julgada foi reconhecida com base na tríplice identidade exigida pelo $\mathrm{CPC}$, extinguindo-se AIME que repetia as partes, a causa de pedir e o pedido de AIJE ${ }^{510}$. Já em um segundo caso, a litispendência foi reconhecida com base na identidade da "relação jurídica-base das demandas", embora distintas as partes, uma vez que há "plena identidade de fatos e provas já examinados pela instância julgadora em feito anterior, sem que se tenha elemento novo a ser considerado, como, por exemplo, quando descobertas novas provas ou se pretenda a reunião de fatos isolados" que podem, em seu conjunto, revestir-se de gravidade que não ostentavam isoladamente $\mathrm{e}^{511}$.

\section{ELEIÇÕES 2010. AGRAVO REGIMENTAL. RECURSO CONTRA EXPEDIÇÃO DE DIPLOMA. CONVERSÃO EM AÇ̃̃O DE IMPUGNAÇÃO DE MANDATO ELETIVO E REMESSA PARA O TRE. 1. Na linha da jurisprudência firmada para as eleições de 2010,"o recurso con- tra expedição de diploma com base no art. 262, IV, do Código Eleitoral deve ser recebido como ação de im- pugnação de mandato eletivo, em razão do princípio da segurança jurídica, e remetido ao Tribunal Regional Eleitoral" (AgR-AgR-RCED no 8-09/MA, rel. Min. Henrique Neves da Silva, julgado em 10.4.2014). Esse entendimento não exclui a possibilidade de o Tribunal analisar eventual litispendência ou coisa julgada quando o recurso contra expedição de diploma é cópia fiel da ação de investigação judicial eleitoral, prestig- iando o art. 5\%, inciso LXXVIII, da CF/1988, segundo o qual,"a todos, no âmbito judicial e administrativo, são assegurados a razoável duração do processo e os meios que garantam a celeridade de sua tramitação”. 2. No caso concreto, há coisa julgada formada na AIJE n 1919-42/AC, julgada improcedente pelo Regional e mantida pelo TSE, o que impede a apreciação do RCED, considerando a identidade de parte, causa de pedir e pedido. 3. Agravo regimental provido. (AgR-RCED 31539/AC, Rel. Ministro GILMAR MENDES, \\ DJE 23/10/2015, sem grifos no original)}

\section{RECURSO ESPECIAL. AÇÃO DE IMPUGNAC̨ÃO DE MANDATO ELETIVO. ABUSO} DO PODER ECONÔMICO. CAPTAÇÃO ILÍCITA DE SUFRÁGIO. LITISPENDÊNCIA. 1. A litispendência entre feitos eleitorais pode ser reconhecida quando há identidade da relação jurídica-base das demandas, não sendo possível afirmar aprioristicamente e de forma generalizada a impossibilidade de sua ocorrência. 2. As análises das situações fáticas e de direito que impõem o reconhecimento da litispendência devem ser feitas à luz do caso concreto. 3. A litispendência pode ser verificada quando há plena identidade de fatos e provas já examinados pela instância julgadora em feito anterior, sem que se tenha elemento novo a ser considerado, como, por exemplo, quando descobertas novas provas ou se pretenda a reunião de fatos isolados que, por si, podem ser insignificantes, mas no conjunto são aptos a demonstrar a quebra dos princípios constitucionais que regem as eleições. 4. Hipótese em que o Tribunal de origem registrou a completa identidade entre os fatos apurados no feito e os examinados em representação anterior, cujo pedido foi julgado procedente para cassar o mandato do representado. Litispendência reconhecida. (Respe 348, Rel. Ministro HENRIQUE NEVES, julgado em 12/11/2015, DJE - Diário de justiça eletrônico, Tomo 233, Data 10/12/2015, Página 127). 
O que distingue os casos é que, no primeiro, aplica-se a noção de identidade de ações própria do processo individual $\mathrm{e}$, no segundo, adere-se, ainda que de modo não expresso, ao entendimento prevalente sobre essa identidade no processo coletivo. Rememorando-se aqui que, conforme sistema vigente, a legitimidade ativa das ações coletivas é entregue a representantes adequados, que atuam como substitutos processuais, parte significativa da literatura defende que a repetição de demanda coletiva se configura mesmo se distintas as partes autoras da primeira e da segunda ação. Confira-se, por todos, o posicionamento de Fredie Didier Jr.:

[...] é possível cogitar litispendência ou coisa julgada mesmo sem a existência da chamada tríplice identidade. No âmbito das causas coletivas, por exemplo, a verificação da litispendência e da coisa julgada prescinde da identidade das partes (basta a identidade de pedido e da causa de pedir). Nas causas coletivas, há inúmeros colegitimados legalmente autorizados a atuar na defesa da mesma situação jurídica coletiva (mesmo direito), cuja titularidade pertence a um único sujeito de direitos (a coletividade). Logo, o que importa para a configuração da identidade de demandas é a precisa correspondência entre o pedido e a causa de pedir, uma vez que vários são os extraordinariamente legitimados a demandar no interesse do sujeito titular da relação substancial deduzida ("o agrupamento humano"). ${ }^{512}$

Essa solução, contudo, desafia crítica. Não se discorda, aqui, da premissa: as ações eleitorais que podem conduzir ao impedimento ou extinção de candidaturas, diplomas e mandatos têm caráter coletivo, porque dizem respeito à representatividade política. Ademais, seu manejo é entregue a representantes adequados, que substituem os principais interessados - a saber, eleitores e, mesmo, a população potencialmente governada ou representada pelo candidato ou eleito. Mas é precisamente em decorrência da adoção do modelo de representação adequada que se torna temerário pronunciar a litispendência com base na coincidência de causa de pedir e pedido. Afinal, essa medida converte o legitimado que primeiro age em titular absoluto da prerrogativa de formatar e conduzir a discussão de uma questão coletiva. Combinado com a legitimidade disjuntiva, esse entendimento sobre a configuração da identidade de ações faz com que mesmo os demais legitimados ativos fiquem impedidos de integrar o debate judicial.

\subsection{Reunião de processos: a problemática novidade trazida pela Lei $13.165 / 2015$}

Com o advento da Lei 13.165/2015, todavia, um novo elemento precisará ser considerado. O recém introduzido art. 96-B da Lei 9.504/97 sugere solução diferente daquela adotada pelo TSE para o caso de açóes eleitorais que, propostas por partes diversas, versem sobre o mesmo fato. Segundo a previsão legal, devem as ações serem reunidas para julgamento conjunto perante o juízo prevento, a qualquer tempo antes do trânsito em julgado, convertendo-se o autor da segunda ação em litisconsorte na primeira. Se, porém, a segunda ação for ajuizada após o trânsito em julgado da primeira, aquela somente será conhecida se indicar novas provas ${ }^{513}$.

512. DIDIER JR., Fredie. Curso de direito processual civil: introdução ao direito processual civil, parte geral e processo de conhecimento, p. 718 .

513."Lei 9.504/97, Art. 96-B. Serão reunidas para julgamento comum as ações eleitorais propostas por partes diversas sobre o mesmo fato, sendo competente para apreciá-las o juiz ou relator que tiver recebido a 
Note-se que o novo regramento legal: 1) somente se refere à identidade de fatos, omitindo-se quanto à identidade da configuração jurídica dada àqueles, com o que parece aderir à leitura já criticada da teoria da substanciação da causa de pedir; 2) aponta em sentido contrário à Súmula 235 do ST ${ }^{514}$, ao indicar que sejam reunidas uma ação recém proposta com outra já em fase recursal; 3) cinde o regime de tratamento das ações que versem sobre o mesmo fato, reconhecendo a ocorrência de coisa julgada (e, portanto, a identidade de ações) se a primeira ação já tiver transitado em julgado e negando a ocorrência de litispendência (e, portanto, afastando a identidade de ações) se a primeira ação ainda estiver em curso.

Já diante dessas primeiras constatações sobre o art. 96-B da Lei 9.504/97, avista-se a possibilidade de que novos desdobramentos surjam na questão da litispendência e da coisa julgada entre as ações eleitorais, especialmente porque parecem inconciliáveis a posição mais recente do TSE e a nova regra legal.

Há, porém, um ponto de toque entre essas posições: tanto o direcionamento mais recente do TSE quanto a novel previsão legal têm em mira promover a celeridade e combater o risco de "decisões conflitantes", assim consideradas como aquelas que promovam julgamentos distintos sobre ações que versem sobre os mesmos fatos. Essa noção de "decisões conflitantes" aparece bem delineada no voto-vista do Min. Castro Meira no já citado julgamento do RCED 8-84, no qual o TSE concluiu pela inconstitucionalidade do inciso IV do art. 262 do Código Eleitoral. Segundo o Ministro:

[...] há que se considerar as dificuldades decorrentes da admissibilidade de mais de uma ação eleitoral fundamentada em idênticos fatos e com o mesmo objetivo, qual seja, a desconstituição do diploma. Essa circunstância, além de proporcionar um número crescente de açóes nesta Justiça Especializada, comprometendo a eficiência da prestação jurisdicional, traz o risco imanente de decisões conflitantes.

$\mathrm{Na}$ prática, é comum o ajuizamento de AIME e RCED com fundamento nos mesmos fatos, tendo em vista a jurisprudência desta Corte Superior de que, nessa hipótese, não há litispendência nem coisa julgada (ED-RCED 698, Rel. Min. Felix Fischer, DJe de 5.10.2009); AgR-Respe 26.276/CE, Rel. Min. Marcelo Ribeiro, DJ de 7.8.2008; REspe 28.015/RJ, Rel. Min. José Delgado, DJ de 30.4.2008). Entretanto, em razão das regras de competência, essas ações são julgadas por órgãos jurisdicionais diversos. $\mathrm{O}$ risco de decisões conflitantes, portanto, é intrínseco, o que causa enorme insegurança jurídica.

No entanto, ambas as propostas para lidar com as ações similares propostas por autores diversos parecem insuficientes para equacionar adequadamente o problema divisado. Isso porque tanto a abrupta extinção da segunda ação quanto a tormentosa conversão desta $\mathrm{em}$ apêndice da primeira ação apenas abafam uma distorção resultante do sistema vigente, sem, contudo, em lugar de combate-la. Fala-se, aqui, da insuficiência da estruturação polarizada das

primeira. $\S 1^{\circ} \mathrm{O}$ ajuizamento de ação eleitoral por candidato ou partido político não impede ação do Ministério Público no mesmo sentido. $\$ 2^{\circ}$ Se proposta ação sobre o mesmo fato apreciado em outra cuja decisão ainda não transitou em julgado, será ela apensada ao processo anterior na instância em que ele se encontrar, figurando a parte como litisconsorte no feito principal. $\$ 3^{\circ}$ Se proposta ação sobre o mesmo fato apreciado em outra cuja decisão já tenha transitado em julgado, não será ela conhecida pelo juiz, ressalvada a apresentação de outras ou novas provas."

514. “Súmula 235, STJ. A conexão não determina a reunião dos processos, se um deles já foi julgado." 
ações coletivas, que segue a mesma lógica das ações individuais, para dar conta de questões para as quais convergem múltiplos interessados.

A profusão de ações eleitorais é um reflexo dessa insuficiência pois, uma vez que um dado procedimento já instaurado é incapaz de absorver a complexidade das demandas coletivas, a tendência será sempre que os legitimados ajuízem novas demandas. Por isso, em arremate ao presente estudo, apresenta-se, de lege ferenda, um modelo apto a fornecer resposta mais satisfatória ao problema obra abordado: a ação temática eleitoral.

\section{Ação temática eleitoral: uma resposta técnica ao problema da identidade entre ações eleitorais ${ }^{515}$}

A ação temática eleitoral constitui proposta apresentada ao final de pesquisa de mestrado para viabilizar o encaminhamento de decisóes judiciais eleitorais coletivas por procedimentos que, compatíveis com premissas sustentadas naquela pesquisa como caracterizadoras da processualidade democrática, acolhessem a participação de todos os afetados pela decisão. Nesse artigo, porém, quer-se destacar que a ação temática eleitoral é capaz de propiciar o aprimoramento técnico dos procedimentos eleitorais ainda que mantida a legitimidade ativa das açóes eleitorais restrita aos representantes adequados.

A proposta parte dos estudos de Vicente de Paula Maciel Júnior, que, em crítica à modelo de representação adequada, reconstrói premissas de estruturação das açóes coletivas - não mais a partir da atribuição da legitimidade ativa a determinados sujeitos, mas, sim, a partir da situação fática sobre a qual recai a multiplicidade de interesses - denominado ação temática ${ }^{516}$.

Nesse modelo, não se cogita da necessidade de previsão legal de um rol de sujeitos previamente autorizados a propor a demanda coletiva. Maciel Júnior enfatiza a necessidade de tratamento do objeto do procedimento coletivo como tema, o que significa que o "mérito ou conteúdo da demanda [...] não será formado apenas pelo objeto do pedido constante na petição inicial", mas também por questões formuladas por quaisquer interessados ${ }^{517}$. O tema consiste, assim, em "fatos ou situações jurídicas que afetam os interessados" e seus contornos e profundidade são construídos por todos os partícipes do procedimento ${ }^{518}$.

A modificação desse esquema exige que seja conferida a mesma intensidade e amplitude à participação de todos os legitimados, independentemente de qual deles tenha provocado a instauração do procedimento coletivo. Para tanto, a linearidade da oposição petição inicial/

515. Este capítulo condensa os resultados obtidos em pesquisa de Mestrado da autora no programa de pós-graduação em Direito Processual da PUC-Minas, sob orientação de Vicente de Paula Maciel Júnior. A dissertação de mestrado, intitulada Ação temática eleitoral: uma proposta para a democratização dos procedimentos judiciais eleitorais coletivos, foi defendida em abril de 2014 e pode ser consultada em <http:// www.biblioteca.pucminas,br/teses/Direito_GrestaRM_1.pdf>.

516. MACIEL JÚNIOR, Vicente de Paula. Teoria das ações coletivas: as ações coletivas como ações temáticas. 517. MACIEL JÚNIOR, Vicente de Paula. Teoria das ações coletivas: as ações coletivas como ações temáticas, p. 180 .

518. MACIEL JÚNIOR, Vicente de Paula. Teoria das ações coletivas: as ações coletivas como ações temáticas, p. 178-179. 
contestação deve ser abandonada, dando lugar a um esquema radial: definida a centralidade do tema posto em debate, deve ser assegurada igual oportunidade de dedução de todos os argumentos que convirjam para este ponto central. A sugestão do autor é que "uma vez proposta uma ação coletiva cujo fato tenha ou possa ter repercussões em um número indeterminado de interessados, a lei deveria prever que o juiz publicasse edital dando ciência do ajuizamento da demanda coletiva referente ao fato ' $\mathrm{X}$ ”' 19 .

A petição inicial da ação temática é, portanto, um ato apto a romper a inércia típica da função judicial, mas não a limitar a causa de pedir fática e jurídica. Deve aquela conter uma narrativa lógica que direcione a construção do tema. $\mathrm{O}$ autor pode, desde logo, indicar interessados a serem chamados ao procedimento ${ }^{520}$. Mas, não podendo quaisquer dos legitimados presuntivamente falar em nome de todos, ao autor não assiste a faculdade de delimitar o alcance subjetivo e objetivo da demanda apresentada. Sobre a situação fática ou jurídica objeto da ação pode incidir uma variedade de pretensões, as quais, entre si, podem ser antagônicas, parcialmente coincidentes ou totalmente coincidentes. Daí se delineia o desenho radial da ação temática.

Se nenhum dos legitimados pode restringir o acesso dos demais ao debate processual ou limitar as questóes e teses que o comporão, exige-se uma técnica que permita a integração do objeto da ação pelas proposições enunciadas por todos os interessados. Assim, o edital que divulga a propositura de determinada ação temática assinala a oportunidade para que quaisquer legitimados compareçam ao procedimento e contribuam para a delimitação do tema objeto da ação, relatando fatos, expondo argumentos jurídicos e deduzindo pretensões. Essa proposta inovadora, que coloca em relevo a objetivação do procedimento, é denominada formação participada do mérito e constitui o cerne da ação temática. ${ }^{521}$

A etapa de propositura da demanda, usualmente constituída de petição inicial e contestação, ganha complexidade na ação temática. $\mathrm{O}$ ato de instauração do procedimento coletivo encaminha questionamentos que serão objeto do exame judicial, mas não impede que outras manifestações tenham a mesma aptidão de provocar questóes. A petição inicial não apenas aguarda um contra-ataque - traduzido na dedução, pelo réu, de fatos negativos, impeditivos, extintivos ou modificativos - como também dispara a oportunidade para que novos questio-

519. MACIEL JÚNIOR, Vicente de Paula. Teoria das ações coletivas: as ações coletivas como ações temáticas, p. 180

520. Haverá pessoas e entes cuja configuração como interessados decorrerá da própria narrativa - por exemplo, a alegação de que determinada obra municipal vem provocando abalos na estrutura de um edifício denota o interesse do Município e dos proprietários e moradores dos apartamentos afetados. Mas isso não exclui o possível interesse de terceiros, como proprietários e moradores de edifícios próximos, associações de bairro, empresas corresponsáveis pela obra pública, empregados. Por isso, não cabe a este fixar, de modo definitivo, quem são os interessados, quanto menos atribuir-lhes a posição de réu. A polaridade processual se dilui ante a impossibilidade de que o autor saiba, previamente, qual posição será assumida pelos interessados. No exemplo dado, os partícipes poderiam encaminhar discussão acerca da ameaça de dano a outros imóveis próximos, do transtorno causado à circulação local, da inobservância de normas de segurança e saúde do trabalho.

521. Segundo Maciel Júnior: "As ações coletivas não devem ser rígidas quanto à formação do mérito porque se o fato abrange um número indeterminado de interessados, é natural que dentre eles existam manifestações de vontade em sentidos diferentes e muitas vezes contraditórios. A ação dos diversos interessados difusos deve conduzir a uma possibilidade de "ampliação flexível do mérito do processo coletivo". Se assim não for, corre-se o risco de se transformar a decisão judicial do processo coletivo em uma visão unilateral e representativa apenas de uma parcela dos interessados difusos na questão litigiosa." (MACIEL JÚNIOR, Vicente de Paula. Teoria das ações coletivas: as ações coletivas como ações temáticas, p. 180.). 
namentos sejam aditados ao mérito. A demanda inicial, dilatada pelo aporte de múltiplas indagações inter-relacionadas a partir de um eixo central - a situação fática ou jurídica que constitui a causa de pedir da petição inicial - converte-se em tema, em mérito construído coletivamente.

Maciel Júnior não renuncia à estipulação legal da fase procedimental que comporta a oportunidade de participação na formação do mérito ${ }^{522}$. A ampliação flexível do mérito constitui uma técnica pontual para compatibilização da fase da propositura com o caráter difuso das questóes coletivas. A essa fase segue a estabilização da demanda, que vincula a atividade instrutória e decisória.

Apresentada, em linhas gerais, a técnica procedimental da ação temática, passa-se a cogitar da perspectiva de sua aplicação ao âmbito da função judicial eleitoral.

\section{4+1. Aplicação da ação temática no âmbito da função judicial eleitoral a ação temática eleitoral}

A ação temática eleitoral é uma proposta de objetivação dos procedimentos eleitorais cujas providências têm repercussão sobre a coletividade. A premissa é que o tema - o fato jurídico discutido -, e não a atribuição subjetiva de titularidade para a propositura da ação, deve constituir o eixo estruturante do procedimento.

Trata-se de premissa similar à encampada recentemente pelo TSE no já citado julgamento do Respe 348, no qual ressaltado que é determinante para a identificação da ação eleitoral a "relação jurídica-base". Mas, ao contrário do que ocorreu nesse julgamento, isso não conduz a que seja desconsiderada a relevância da atuação dos colegitimados - fundamento que é inferido da determinação da extinção da segunda ação. Na ação temática eleitoral, o reconhecimento de que o tema delimita a ação faz com que seja necessário assegurar a todos os interessados (ou, tomado o sistema vigente, ao menos aos demais representantes adequados) ingressar no feito na qualidade de parte - o que torna os colegitimados colaboradores recíprocos, e, não, concorrentes entre si.

Também é possível identificar, no art. 96-B da Lei 9.504/97, a adoção da premissa de que são os fatos, e não as partes, o elemento determinante para o delineamento de uma ação eleitoral. Porém, o citado artigo - caso venha a ser aplicado em sua literalidade - constituirá um lamentável retrocesso técnico processual, uma vez que a reunião de processos, conforme determinada, atropela a sucessão de etapas lógicas do processo e o regime de preclusóes e ignora a relevância da escolha da causa de pedir jurídica para as açóes eleitorais. Na ação temática eleitoral, com a demarcação da etapa de formação participada do mérito, assegura-se aos legitimados ativos que compareçam, ainda na fase postulatória, para densificar o debate processual, quer atribuindo nova configuração jurídica aos fatos narrados, quer indicando fatos correlatos, quer apontando novas provas. Uma vez que esse adensamento ocorre dentro da fase própria - e, não, como sugere o art. 96-B, em uma surpreendente reviravolta, quiçá em fase recursal - assegura-se o adequado exercício do direito de defesa e o desenvolvimento do procedimento como uma sequência ordenada de atos, tal como preceituado por Fazzalari ${ }^{523}$.

522. MACIEL JÚNIOR, Vicente de Paula. Teoria das ações coletivas: as ações coletivas como ações temáticas, p. 183-184.

523. Na teoria estruturalista de Fazzalari, a forma no processo consiste em um esquema enunciador de conteúdos normativos. O "esquema do procedimento é uma sequência de normas e, portanto, de atos valorados, neles incluído o ato final para cuja formação conspiram”. (FAZZALARI, Elio. Instituições de direito processual. 8. ed. Tradução Eliane Nassif. Campinas: Bookseller, 2006, p. 80-81). A principal caracte- 
Assim, a ação temática eleitoral encaminha uma nova perspectiva de tratamento da questão da identidade entre ações eleitorais: em lugar de concentrar-se em restringir a propositura de ações idênticas, assegura-se a ampliação da participação e do debate já diante da primeira ação proposta. Assegurado o ingresso e a contribuição para a formação participada do mérito, tem-se ao menos dois efeitos: 1) no âmbito endoprocessual, propicia-se a maior densidade da discussão e da atuação dos legitimados, minimizando o risco de condução deficiente da defesa do bem jurídico; 2) no âmbito exoprocessual, desencoraja-se a multiplicação de ações similares e permite-se, sem prejuizo da atuação de qualquer colegitimado, já que todos puderam integrar a ação temática proposta, reconhecer a litispendência e a coisa julgada por identidade de causa de pedir.

Relevante esclarecer uma peculiaridade da delimitação dos temas das açôes temáticas eleitorais: a aplicação da técnica da ação temática ao âmbito da função judicial eleitoral deve considerar a sucessividade das etapas do período eleitoral. Ao contrário do que ocorre em outros campos do direito difuso, os temas eleitorais têm momento próprio de configuração, pois acompanham a preparação, a realização e o resultado das eleições.

\subsubsection{Legitimidade da candidatura como tema}

O período eleitoral se inicia com a realização das convenções partidárias para celebração de coligações e escolha dos candidatos e com o requerimento aos órgãos judiciários eleitorais do registro das candidaturas. A legislação prevê a publicação de uma lista de candidatos, que abre ensejo para a atuação direta dos candidatos cujos registros não foram requeridos pelo partido político e, ainda, para a impugnação dos registros requeridos, por alegada ausência de algum dos requisitos legais para o deferimento da candidatura ${ }^{524}$. Conforme prevista atualmente, a AIRC instala uma relação polarizada entre o autor da ação (Ministério Público Eleitoral, partido político, coligação ou candidato) e o candidato cujo requerimento de registro é impugnado.

A análise das questóes referentes ao registro de candidatura desenvolve-se em sedes variadas: aferição dos requisitos da candidatura pelos próprios órgãos judiciários, ajuizamento de AIRCs por legitimados distintos e, ainda, arguição de inelegibilidade sem estabelecimento de contraditório. Tem-se um cenário de multiplicação de procedimentos e incidentes que afluem para um mesmo tema - a legitimidade da candidatura requerida -, cuja tramitação, embora simultânea, não permite a comunicação entre os partícipes. O que há, portanto, é a proliferação de discussões paralelas e sobrepostas, com segmentação do tema.

rística do esquema do procedimento é, para o autor, que o exercício da posição jurídica subjetiva resultante de uma norma se torna fatispécie da norma subsequente, estabelecendo um encadeamento que é requisito de validade do ato final (FAZZALARI, Elio. Instituições de direito processual, p. 114-115).

524. A previsão da publicação da lista de candidatos encontra-se no Código Eleitoral: "Protocolado o requerimento de registro, o presidente do Tribunal ou o juiz eleitoral, no caso de eleição municipal ou distrital, fará publicar imediatamente edital para ciência dos interessados." (Código Eleitoral (1965). Lei n. 4.737, de 15 de julho de 1965, art.97.). A Lei n. 9.504/1997 toma-a como referência para o requerimento do registro de candidatura pelo próprio candidato: "Na hipótese de o partido ou coligação não requerer o registro de seus candidatos, estes poderão fazê-lo perante a Justiça Eleitoral, observado o prazo máximo de quarenta e oito horas seguintes à publicação da lista dos candidatos pela Justiça Eleitoral." (BRASIL. Lei n. 9.504, de 30 de setembro de 1997, art. 11, §4). A referência à publicação dessa lista como termo inicial para propositura da Ação de Impugnação ao Registro de Candidatura está na Lei Complementar n. 64/1990: “Caberá a qualquer candidato, a partido político, coligação ou ao Ministério Público, no prazo de 5 (cinco) dias, contados da publicação do pedido de registro do candidato, impugná-lo em petição fundamentada." (BRASIL. Lei Complementar n. 64, de 18 de maio de 1990, art. $3^{\circ}$.). 
Propugna-se, então, que a publicação da lista de candidatos, já prevista na legislação, seja tomada como ponto de partida para a coletivização do debate em torno da legitimidade da candidatura.

O requerimento do registro de candidatura pelo partido político, pela coligação ou pelo próprio candidato, apesar de voltado para uma providência de gozo individual, desdobra-se em uma questão de inelutável alcance coletivo. À pretensão de deferimento da candidatura subjaz a alegação de preenchimento de todos os requisitos legais para habilitação à disputar cargos eletivos. Eleitores exercerão o direito de voto em relação ao rol de candidatos e deste rol serão extraídos os ocupantes dos cargos nos parlamentos e nos governos.

Trata-se de debate ínsito ao âmbito objetivo do direito difuso, já que a decisão pelo deferimento ou não das candidaturas produzirá efeitos uniformes na circunscrição daquela eleição. Por conseguinte, os interessados, ainda que a princípio indeterminados, devem ter a oportunidade de se apresentarem como partícipes processuais, exercendo, à vista da publicação da lista de candidatos, a prerrogativa de fiscalizar o atendimento aos requisitos legais para a candidatura.

Não há motivos para que essa participação se dê pelo ajuizamento de outra ação, incidental ao requerimento de registro, ou pela desprestigiada arguição de inelegibilidade. Todas as manifestações devem aportar no procedimento já instaurado, contribuir para a delimitação do tema pela pertinência lógica dos argumentos e vincular a decisão, que deve resolver todas as questões suscitadas. A participação deve se estender à produção ampla de provas, o que possibilita a juntada de documentos diretamente por qualquer cidadão, sem a intermediação do Ministério Público Eleitoral. Desse modo, haverá um procedimento único, em que se desenvolverá o debate ampliado, com participação de todos os interessados em contraditório, concentração dos argumentos jurídicos e intensificação da atividade probatória.

\subsubsection{Legitimidade das eleições e de seu resultado como tema}

Ultrapassada a etapa do registro de candidatura, toma lugar a discussão em torno da legitimidade das eleições e de seus resultados. A fiscalidade recai sobre o comportamento de candidatos, partidos, seus apoiadores e eleitores na disputa eleitoral. Surgem questóes concernentes à observância das normas relativas à igualdade entre os concorrentes, à higidez da campanha, ao respeito à liberdade do exercício do voto e à não superveniência de causa que torne ilegítima a permanência na disputa ou a conquista do mandato.

Esses temas ganham complexidade porque não mais se trata, apenas, da aferição de requisitos objetivos para a habilitação de candidatos. Esta aferição objetiva permanece possível, constituindo o objeto do RCED. Mas, por meio da AIJE, das representaçóes específicas e da AIME, abre-se oportunidade para a apuração de práticas ilícitas ${ }^{525}$ ocorridas já no contexto da disputa eleitoral, com repercussão sobre a participação dos candidatos nas eleições e com eventual comprometimento do resultado destas.

Todas as questôes a serem discutidas nos procedimentos vigentes concernem à legitimidade das eleições e de seu resultado. Não há porque, sob a ótica da reestruturação proposta,

525. A referência aqui é aos ilícitos eleitorais, entendidos como condutas que ensejam a imposição de providências eleitorais gravosas, isto é, providências determinadas no âmbito da função judicial eleitoral. Não se trata, portanto, dos denominados crimes eleitorais, que são ilícitos criminais remetidos à competência dos órgãos judiciários eleitorais. 
conferir-lhes um tratamento compartimentado ${ }^{526}$.

Adotada a técnica da ação temática eleitoral, o procedimento para a apuração de ilícitos eleitorais passaria a ser único. A propositura da ação eleitoral coletiva por qualquer legitimado deve ensejar a publicação de edital que explicite a situação fática e a configuração jurídica ${ }^{527}$ que conduzem à alegação de que houve vulneração da legitimidade das eleições ou de seus resultados. Além da obrigatória cientificação daqueles a quem o autor imputa práticas ilícitas e da necessária intervenção do Ministério Público, o procedimento se abre à participação dos demais colegitimados. No prazo assinalado, todos podem acrescentar fatos e também conferir nova configuração jurídica aos fatos já aduzidos.

Como os limites do tema conformam a coisa julgada, a adoção da ação temática não significa que somente um procedimento possa ser instaurado em relação a cada eleição disputada. O mais significativo, em perspectiva democrática, é que a adoção da ação temática torna possível que um maior número de questóes coletivas seja tratado conjuntamente e com participação de todos os que se autoproclamarem interessados.

Isso é relevante porque a estabilização da demanda, que ocorre com a decisão saneadora, impede a modificação do tema após a fase postulatória (entre o ajuizamento e o prazo do edital de cientificação dos interessados). Mas as irregularidades e práticas ilícitas posteriores ou conhecidas posteriormente à fase de propositura de uma ação temática eleitoral poderão embasar o ajuizamento de nova ação, sob os mesmos moldes. O objeto dessa segunda ação, também formado participadamente, não poderá incluir questões já deduzidas na primeira ação.

Cabe, ao final, um apontamento sobre o RCED. Em face da atual redação do art. 262, essa ação eleitoral passa ter configuração bastante específica, destinada à aferição objetiva da ocorrência de inelegibilidade superveniente ao registro de candidatura, inelegibilidade constitucional ou ausência de condição de elegibilidade. Foram eliminadas as hipóteses de cabimento que tangenciavam o abuso de poder econômico e a captação ilícita de sufrágio. Com isso, é provável que o manejo do RCED passe a ficar à margem da questão sobre a litispendência em relação a outras ações. Mas, ainda assim, se pode cogitar da propositura de mais de um RCED por legitimados diversos. Seja como for, nada impede a aplicação do modelo da ação temática eleitoral a seu objeto, em conformação aproximada à da AIRC, também destinada à aferição de impedimentos pré-existentes a sua propositura.

526. São esperadas objeções quanto ao tratamento coletivo das causas de pedir que embasam a Ação de Impugnação ao Mandato Eletivo, em função de ser esta prevista constitucionalmente. No entanto, é pertinente observar que a Ação de Impugnação ao Mandato Eletivo não tem procedimento legalmente estipulado e que, se a jurisprudência deliberou fixar a subsunção dessa ação constitucional ao rito da Ação de Impugnação ao Registro de Candidatura, nada impede a adoção da aqui nominada ação temática eleitoral para tal propósito.

527. Assinale-se que, de acordo com as premissas teóricas já traçadas, o tema deve ser enunciado a partir da narrativa fática e também da configuração jurídica dada aos fatos. Conforme visto no exemplo acima apresentado, a mesma conduta pode sugerir a prática de ilícitos diversos. Como cada um desses ilícitos exige elementos próprios para sua configuração, o contraditório deve se estabelecer não apenas em torno dos fatos, mas também desses elementos. $\mathrm{O}$ adequado exercício do direito de defesa exige que a imputação da prática ilícita esteja delimitada em seus termos nucleares, fáticos e jurídicos, somente podendo haver condenação dentro desses limites. Esta, ao que parece, a aplicação da teoria da substanciação que se mostra compatível com o Estado Democrático de Direito. A aplicação extremada dessa teoria, com prevalência ao antigo adágio "dai-me os fatos que te darei o direito", tem por pressuposto o protagonismo judicial e propicia que seja proferida condenação por fundamento jurídico desconectado do debate processual, assim legitimando a decisão surpresa. 


\section{Considerações finais}

Ao final do presente artigo, espera-se que a discussão trazida tenha sido capaz de suscitar a importância do tratamento técnico e científico dos procedimentos eleitorais, rumo à construção de um Direito Processual Eleitoral. O controle judicial da legitimidade das candidaturas, das eleições e de seus resultados possui viés coletivo inegável, o que exige a superação de diretrizes extraídas do processo individual, frequentemente aplicadas de modo irrefletido.

Assim, se a discussão em torno da identidade de ações eleitorais vem crescentemente se tornando uma questão que preocupa os tribunais, espera-se que o equacionamento dessa questão tome em consideração premissas do processo coletivo e, mais, de uma compreensão deste fundada em teorização democrática. Para tanto, é preciso, primeiramente, compreender as particularidades dos elementos das açóes eleitorais, a fim de que se possa construir regras para o reconhecimento da litispendência e da coisa julgada sem comprometimento da proteção aos bens jurídicos resguardados pelas ações eleitorais coletivas.

Nesse mister, o artigo abordou a configuração das partes, do pedido e da causa de pedir da AIRC, da AIJE, das representaçóes específicas, da AIME e do RCED. Diagnosticou a identidade entre essas ações como um efeito colateral das investidas fragmentadas do Direito Eleitoral em sua função de controle da legitimidade das candidaturas, das eleições e de seus resultados. Em seguida, problematizou as duas mais recentes propostas de tratamento da identidade entre essas ações: a dispensa da tríplice identidade, por julgados de 2015 do TSE, e a reunião de processos baseados nos mesmos fatos, pelo art. 96-B da Lei 9.504/97, inserido pela Lei 13.165/2015. Identificou-se nelas, contudo, um viés comum: a preocupação em evitar decisões conflitantes, decorrente do reconhecimento de que é a situação fática trazida naquelas ações o elemento determinante para sua identificação.

Partindo dessa premissa comum, o artigo mostrou uma nova possibilidade de enfrentamento da questão: a ação temática eleitoral, procedimento coletivizado, apto a receber maior número de participantes e de propiciar a ampliação da discussão dos fatos atinentes à legitimidade das candidaturas, das eleiçóes e de seu resultado, por meio da técnica de formação participada do mérito.

Defende-se que a adoção da ação temática eleitoral é apta a superar a conturbada técnica procedimental vigente que, ao tempo que restringe a participação dos interessados e a ampla fiscalidade da legitimidade das eleições e de seus resultados, propicia a proliferação de ações com objetos similares ou idênticos.

Ao final, cabe pontuar que a presente proposta, de cunho acadêmico, não ignora ser indispensável a regulamentação legal da ação temática eleitoral.

\section{Referênciass bibliográficas}

ADAMOVICH, Eduardo Henrique Raymundo Von. Os belos copos de vinho da vovó? Elementos de história do processo coletivo para a solução de alguns problemas supostamente intrincados. In: RIBEIRO JÚNIOR, José Hortêncio et al (Org.). Ação coletiva na visão de juízes e procuradores do trabalho, p. 23-44. São Paulo: LTr, 2006. 
ALMEIDA, Gregório Assagra de. Manual das ações constitucionais. Belo Horizonteः Del Rey, 2007.

BUENO, Cassio Scarpinella. Curso sistematizado de direito processual civil: teoria geral do direito processual civil. 5. ed. São Paulo: Saraiva, 2011.

CÂMARA, Alexandre Freitas. Lições de direito processual civil: volume 1. 25. ed. São Paulo: Atlas, 2014 .

CAPPELLETTI, Mauro; GARTH, Bryant. Acesso à justiça. Tradução de Ellen Gracie Northfleet. Porto Alegre: Sérgio Antônio Fabris Editor, 1988.

CASTELLS, Manuel. A sociedade em rede. $14^{\text {a }}$ reimpressão com novo prefácio. São Paulo: Paz e Terra, 2011. (A era da informação. Economia, sociedade e cultura ;1).

COSTA, Adriano Soares da. Instituições de direito eleitoral. 9. ed. rev. ampl. e atual. Belo Horizonte: Fórum, 2013.

DIDIER JR., Fredie. Curso de direito processual civil: introdução ao direito processual civil, parte geral e processo de conhecimento. 17. ed. rev. ampl. e atual. Salvador: Jus Podivum, 2015.

FAZZALARI, Elio. Instituições de direito processual. 8. ed. Tradução Eliane Nassif. Campinas: Bookseller, 2006 .

GOMES, José Jairo. Direito eleitoral. 11. ed. rev. atual. e a ampl.. São Paulo: Atlas. 2015.

LASCALA, Maria Carolina Florentino; COSTA, Yvete Flávio da. A litispendência nas ações coletivas. In: Revista electronica do curso de Direito da UFSM, v. 5, n. 3 (2010). Disponível em: <http://cascavel.ufsm.br/revistas/ojs-2.2.2/index.php/revistadireito/article/ view/7057\#.VsMusJMrKi4>. Acesso em: 10 fev. 2016.

LÔBO, Edilene. A inclusão do cidadão no processo eleitoral. Belo Horizonte: Del Rey, 2010.

MACIEL JÚNIOR, Vicente de Paula. Teoria das ações coletivas: as ações coletivas como ações temáticas. São Paulo: LTr, 2006.

NUNES, Dierle José Coelho. Processo jurisdicional democrático. Curitiba: Juruá, 2008.

PEREIRA, Rodolfo Viana. Tutela coletiva no direito eleitoral: controle social e fiscalização das eleições. Rio de Janeiro: Lumen Juris, 2008.

RIBEIRO, Fávila. Pressupostos constitucionais do direito eleitoral: no caminho da sociedade participativa. Porto Alegre: Sergio Antonio Fabris Editor, 1990.

VIGORITI, Vincenzo. Interessi collettivi e processo: la legitimazione ad agire. Milano: Giuffrè, 1979. 
Recebido emः 16/02/2016

Aceito em: 24/03/2016

\section{Como citar}

GRESTA, Roberta. $O$ problema da identidade entre açóes eleitorais: da litispendência e da coisa julgada à ação temática eleitoral. Ballot. Rio de Janeiro: UERJ. Volume 2 Número 1 Janeiro/Abril 2016. pp. 286-312. Disponível em: [http://www.e-publicacoes.uerj.br/index.php/ballot]

\section{(c) (1) $\$(0)$}

A Revista Ballot está licenciada sob uma licença Creative Commons Atribuição - Não Comercial - Compartilha Igual 3.0 Não Adaptada. 